\title{
95 Percent Maximal Inhibitory Concentration Reference Control Result Measurement
}

National Cancer Institute

\section{Source}

National Cancer Institute. 95 Percent Maximal Inhibitory Concentration Reference

Control Result Measurement. NCI Thesaurus. Code C116252.

A reference control sample response based on a concentration of a specific drug expected to produce $95 \%$ inhibition of the standard growth of a viral organism, or of a biological/biochemical reaction. 